\title{
O analista como testemunha
}

\author{
Jô Gondar* \\ Diego Frichs Antonello ${ }^{1}$ \\ Universidade Federal do Estado do Rio de Janeiro, Centro de Ciências Humanas e Sociais, \\ Programa de Pós-Graduação em Memória Social. Rio de Janeiro, RJ, Brasil
}

Resumo: A proposta deste artigo é pensar o lugar da testemunha como um lugar terceiro que o analista, na clínica do traumático, é capaz de sustentar. Nos sonhos traumáticos, segundo Ferenczi, já existe a convocação de um terceiro. Não se trata da testemunha da esfera do Direito, tampouco do lugar do pai ou da Lei simbólica. Trata-se de um terceiro espaço que pode ser chamado de potencial, espaço intersticial, indeterminado e informe no qual circula -e aos poucos ganha forma -, algo que a princípio seria incomunicável. Esse espaço permite e suporta a literalidade da narrativa testemunhal, seus titubeios, paradoxos e silêncios. Mais do que uma teoria do trauma, a noção de espaço potencial seria a grande contribuição da psicanálise às pesquisas teóricas e clínicas com sobreviventes de campos de extermínio, de situações de tortura e de violência.

Palavras-chave: trauma, testemunha, espaço potencial, clínica, psicanálise.

Há alguns anos tem se fortalecido a contribuição mútua entre a psicanálise e a literatura de testemunho. O trabalho com sobreviventes de campos de extermínio, tortura e violência costumam destacar o efeito terapêutico desse tipo de relato: dar testemunho da própria história e do próprio sofrimento, endereçando-os a alguém, seria uma forma de elaboração das vivências traumáticas. É compreensível, então, que a psicanálise seja tão frequentemente invocada pela literatura de testemunho. Ela não só produziu teorias consistentes sobre o trauma como também um dispositivo clínico que é, em si mesmo, uma situação testemunhal. Porém as contribuições que as narrativas de sobreviventes trazem à clínica psicanalítica não são menos importantes. A maior delas consiste em reconhecer que a clínica do traumático põe em jogo algo mais do que uma narrativa e sua escuta. Como podemos observar na literatura de testemunho, não se trata simplesmente de narrar o que aconteceu, mas de fazê-lo ao mesmo tempo que se admite que o que aconteceu não faz parte do narrável. Sem o reconhecimento desse paradoxo o efeito terapêutico não se dá, ou ocorre de maneira enfraquecida.

Neste artigo pretendemos enfocar a clínica do traumático desde o paradoxo que lhe é próprio, mas por outra perspectiva - a de quem ouve a narrativa paradoxal, o psicanalista. Não seria ele também uma testemunha? E, nesse caso, qual o valor terapêutico dessa função, quando referida ao analista? Que atitude tomar diante de sujeitos que narram o impossível?

1 Bolsa CAPES, relativa ao doutorado no Programa de Pós-Graduação em Memória Social (UNIRIO). Processo no 1143337.

* Endereço para correspondência: jogondar@uol.com.br

\section{Sonho e trauma}

Podemos iniciar essa reflexão com aquilo que, a partir dos anos 1920, tornou-se o núcleo dos estudos psicanalíticos sobre o trauma: o sonho traumático. A função do sonho traumático e o quanto ele se aproxima ou se distancia da situação testemunhal são aspectos importantes em nossa discussão. É bastante conhecida a teoria freudiana dos sonhos: a busca de realização de um desejo recalcado é a principal função onírica, sendo o sonho traumático uma exceção a essa regra. Exceção na medida em que o impacto do trauma impede o trabalho de elaboração onírica, colocando fora de cena não só o desejo como os mecanismos através dos quais ele é distorcido e disfarçado no sonho - a condensação e o deslocamento.

Bem menos conhecida é a teoria de Ferenczi a esse respeito. Em 1931 ele escreve sua Revisão de "A interpretação de sonhos", promovendo uma completa reversão da proposta freudiana. Aquilo que em Freud se colocava como exceção torna-se, em Ferenczi, o paradigma do funcionamento onírico. Para ele, a função primordial do sonho é traumatolítica, isto é, seu intuito principal é o de desfazer-se do choque, sendo a realização de desejo apenas uma forma particular dessa tendência: "Uma definição mais completa da função do sonho seria (em vez de 'o sonho é uma realização de desejo'): todo e qualquer sonho, ainda o mais desagradável, é uma tentativa de levar acontecimentos traumáticos a uma resolução" (Ferenczi, 1934/1992, p. 112). Mas de que modo liquidar os traumas somente com a repetição compulsiva das cenas chocantes, sem possibilidade de elaboração onírica?

É aqui que Ferenczi fornece contribuições importantes para a clínica do traumático. Para ele, a elaboração é possível nesses casos, mas sob uma forma diferente: ao invés do trabalho onírico se fazer através da condensação 
ou do deslocamento, ele se dá pela figurabilidade e pela repetição. A figurabilidade foi um dos mecanismos do sonho descritos por Freud, e consiste na possibilidade de expressar alguma coisa por meio de imagens. Ela implica um trabalho psíquico ao criar uma imagem na qual não existia nada antes, ou existia apenas enquanto impressão sem forma. Dar uma forma a uma vivência traumática significa, primeiramente, figurá-la. Essa figuração faz um primeiro tipo de enlace de uma intensidade que se encontrava em estado bruto, transformando-a em imagens que são a expressão do trauma e, ao mesmo tempo, sua primeira elaboração. Paul Klee gostava de dizer que "a arte não reproduz o visível, ela torna visível". O mesmo poderia ser dito quanto aos sonhos traumáticos. Ao receber uma imagem visual, uma vivência terrível pode ser evocada, descrita e transmitida, tornando visível alguma coisa que até então se mostrava invisível, indizível e intolerável.

A outra possibilidade de elaboração no sonho se dá através da repetição. É bom lembrar que Ferenczi não encara de maneira negativa a compulsão à repetição, bem ao contrário: ele lhe fornece um estatuto criativo e curativo. Se Derrida diz que "é certo que a vida se protege pela repetição" (Derrida, 1967/1995, p. 188), Ferenczi vai mais longe: para ele, a vida se expande e se cura pela repetição. Mas de que modo? Em primeiro lugar, ele considera que os flashbacks visam o desgaste e o enfraquecimento dos choques. Pela repetição, a situação traumática vai perdendo sua dimensão de susto, de surpresa. Em segundo lugar, ele pensa que a repetição no sonho deixa de ser uma reprodução cega, porque nesse caso as cenas traumáticas são produzidas pelo próprio sujeito, implicando uma mudança da passividade para a atividade. É como se através dos sonhos o sujeito produzisse ativamente o trauma, com o intuito de dominá-lo e liquidá-lo. Trata-se de uma atitude paradoxal que acontece não apenas na atividade onírica, mas também nos comportamentos autodestrutivos que podem sobrevir àqueles que vivenciaram traumas: o sujeito aplica em si mesmo o próprio veneno que procura evitar. $\mathrm{O}$ sonho e as compulsões funcionariam, assim, como uma espécie de autovacinação, pela qual o traumatizado administra a si mesmo uma pequena dose de horror para se tornar imune a ele, ou seja, volta-se contra si mesmo, a fim de se preservar. Assim, mesmo quando a atividade onírica é praticamente a reprodução da cena traumática, o movimento repetitivo se dá no sentido da elaboração, pois envolve invariavelmente um trabalho.

Apenas essas duas características - a figurabilidade e a repetição - já estariam indicando que o sonho possui um propósito curativo, visando atingir um novo patamar psíquico no qual os traumas podem ser elaborados e liquidados. Há ainda uma terceira dimensão indicada por Ferenczi, mas pouco explorada por ele, que atesta a potencialidade curativa dos sonhos traumáticos - a dimensão da testemunha. É nela que agora vamos enfocar.

\section{Sonho e testemunha}

Como vimos, Ferenczi faz do sonho traumático o paradigma do funcionamento onírico. $\mathrm{Na}$ descrição e análise de um desses sonhos, contado por uma paciente, Ferenczi mostra a importância psíquica e clínica da função da testemunha.

Uma jovem (uma menina?) está deitada no fundo de uma canoa, quase morta, muito pálida. Um homem gigantesco debruça-se sobre ela, esmagando-lhe o rosto. Na canoa, por trás deles, está um homem de pé, um senhor que ela conhece pessoalmente, e a menina tem vergonha de que esse homem seja testemunha do evento. A canoa está cercada de picos montanhosos extremamente altos e abruptos, de modo que ela não pode ser vista de nenhuma parte, exceto de um aeroplano que voa a uma distância incomensurável. (Ferenczi, 1934/1992, p. 114, itálico nosso)

O que significa, nesse contexto, a função da testemunha?

O sonho expressa bastante bem a clivagem subjetiva do paciente traumatizado; na cena onírica, o eu fragmentado se reparte em diversos personagens. A versão clássica da clivagem, como se sabe, reenvia a uma divisão em duas partes que não se comunicam, ignoram uma à outra e, justamente por isso, não entram em conflito. Trata-se de uma lógica bem diferente daquela do recalque, que implica um conflito entre o eu (instância recalcante) e o inconsciente (instância recalcada). No recalque, a divisão se manifesta entre o eu e um desejo que ele não pode admitir, por ferir a imagem que o sujeito faz de si mesmo, para si ou para os outros. Na clivagem, a ferida é muito mais profunda: o trauma produz um aniquilamento subjetivo que o conduz a uma cisão no seio do próprio eu. Entretanto, uma clivagem não precisa reduzir-se à dualidade, e é exatamente esse o aspecto que o sonho é capaz de ilustrar. Nele, o abuso sexual que uma menina sofre por parte de um adulto é encenado a partir de uma divisão de papéis ou funções que extrapolam o da abusada e do abusador. Um terceiro personagem aparece na cena: a testemunha.

Na figuração onírica, a paciente aparece fragmentada, cindida entre a menina que sofre o abuso e, ao mesmo tempo - devido ao mecanismo de identificação com o agressor -0 adulto que o pratica. "A cena do lago profundo reproduz o espetáculo do homem que não pode dominar-se, a ideia do que o mundo irá dizer, o sentimento de estar morta e em aflição." (Ferenczi, 1934/1992, p. 115). Assim como a menina se divide, a função de testemunha também aparece desdobrada. Ela tanto pode ser exercida de dentro do barco - "A menina tem vergonha de que esse homem seja testemunha do evento" - como de fora dele, de um lugar muito distante: "é, no máximo, Deus quem está no céu ou um aviador voando a grande distância, ou seja, alguém emocionalmente desligado dos acontecimentos, que poderia espiar o que acontece". (Ferenczi, 1934/1992, p. 115). Evidentemente, colocar-se em um lugar externo à cena traumática indica uma possibilidade de distanciamento e de elaboração da situação. Nesse sentido, o próprio fato de 
o sonho comportar um terceiro personagem já estaria indicando o seu potencial terapêutico. Um personagem distante seria capaz de espiar e, justamente devido a uma distância emocional, não sentir vergonha. Esse olhar distante talvez pudesse recolher a cena inteira, reunificando todos os seus personagens. Contudo, o que gostaríamos de destacar, para além dessa capacidade reflexiva do sujeito sobre a própria cena, é o apelo ao outro que o sonho expressa. É aqui que a função da testemunha aparece em sua possibilidade terapêutica ou, ao menos, na expectativa de uma função terapêutica. Existe no sonho um apelo desesperado para que um terceiro possa se instalar na cena traumática. A figura do aviador distante expressa, para Ferenczi, a convocação urgente desse terceiro.

Nesse contexto, a clivagem não é apenas uma reação patológica. Ela é também uma tentativa de sobrevivência e até mesmo de cura do traumatismo. Desde seus primeiros trabalhos, Ferenczi já havia dito que as patologias e as reações aos traumas não deveriam ser pensadas como empecilhos à saúde, mas ao contrário, como "tentativas de autocura". (Ferenczi, 1909/1991, p. 51). Por esse motivo, a presença da testemunha é, ao mesmo tempo, indicação de uma tentativa terapêutica no sonho traumático. O apelo ao terceiro - a testemunha - é um apelo a algo ou alguém que estava ausente no momento em que a situação traumática se deu. É um apelo ao cuidado, à salvação, e, consequentemente, à superação do trauma. A princípio, o próprio sujeito procura ocupar esse lugar de quem vê a cena de fora, esse lugar terceiro.

Um fato surpreendente mas, ao que parece, de valor geral, quando do processo de autodilaceração, é a brusca transformação da relação de objeto, que se tornou impossível, numa relação narcísica. O homem abandonado pelos deuses escapa totalmente à realidade ... e desprende agora um fragmento de si mesmo que, sob a forma de uma pessoa dispensadora de cuidados ... sente piedade da parte restante e atormentada da pessoa, cuida dela, decide por ela ... um anjo da guarda, por assim dizer. Esse anjo ve desde fora a criança que sofre, ou que foi morta (portanto, ele se esgueirou para fora da pessoa durante o processo de "fragmentação"). (Ferenczi, 1934/1992, p. 117, itálicos nossos)

Aqui aparece um sentido a mais para a relação entre o testemunhar e a cura. $\mathrm{O}$ que as pesquisas sobre a literatura de testemunho geralmente enfocam é a dimensão terapêutica da narrativa subjetivada: dar testemunho do próprio sofrimento traumático seria um procedimento capaz de elaborá-lo e atenuá-lo. Porém, no sonho é reforçada uma perspectiva para além dessa: um terceiro - seja Deus, um outro ou uma fragmentação do próprio sujeito - ele é capaz de ver a cena de fora e oferecer ajuda. Isso implica dizer que, para um testemunho ter sentido, é preciso que alguém testemunhe essa fala e essa dor. É preciso que alguém testemunhe o testemunho. E de que modo?

\section{O analista como testemunha}

A palavra "testemunha", em português, condensa dois significados que aparecem separados no latim. Benveniste (1995) nos explica que o primeiro, testis, significa etimologicamente aquele que assiste como um terceiro (terstis) a um caso em que dois personagens estão envolvidos; o segundo, superstes, indica aquele que é testemunha e, ao mesmo tempo, sobrevivente de uma situação, "aquele que se mantém no fato e que se mantém presente" (Benveniste, 1995, p. 278). A literatura de testemunho valoriza principalmente o segundo sentido: Primo Levi, Jorge Semprun, Charlotte Delbo são todos superstites, indivíduos capazes de dar testemunho de uma experiência vivida.

Porém, é fato que os dois sentidos não podem ser rigorosamente separados, como enfatiza Seligmann-Silva (2010). No sonho traumático citado, os dois sentidos do testemunhar comparecem, solidários à fragmentação egoica que a cena onírica pode figurar. $\mathrm{O}$ homem que assiste à situação dentro do barco de algum modo participa dela e da vergonha sentida pela menina, enquanto o aviador - ou Deus - é um terceiro, capaz de, à distância, perceber o que se passa entre todos os personagens.

Contudo, o sujeito traumatizado fracassa quando tenta ocupar esse lugar terceiro. Sua única possibilidade de experimentar a cena à distância é ela mesma cindida e fragmentária, a de um eu que tudo sabe, mas nada sente, de acordo com Ferenczi. Mas essa estratégia fracassa: "O santo protetor deve confessar sua própria impotência e seus embustes bem intencionados à criança martirizada, e nada mais resta, nesta altura, senão o suicídio, a menos que, no derradeiro momento, se produza algo favorável na própria realidade" (Ferenczi, 1934/1992, p. 117). O que pode se produzir de mais favorável na realidade é a presença de um terceiro capaz de estabelecer um contraste entre o presente e um passado insuportável. Ao invés de desprender um fragmento de si, existe agora a possibilidade de não enfrentar sozinho a situação traumática. O lugar terceiro pode advir quando o analista testemunha, na clínica, a repetição do trauma:

Essa coisa favorável a que nos referimos em face do impulso suicida é o fato de que nesse novo combate traumático o paciente não está inteiramente só. Talvez não possamos the oferecer tudo o que lhe caberia em sua infância, mas só o fato de que possamos vir em sua ajuda já proporciona o impulso para uma nova vida. (Ferenczi, 1934/1992, p. 117)

Sob a presença do analista, o traumatismo poderia ser rememorado ou mesmo repetido em condições mais favoráveis, e aquilo que permanecia não inscrito, inacessível ao dinamismo da memória, poderia ser levado, pela primeira vez, à percepção e à descarga motora (Ferenczi, 1934/1992, p. 113). Assim, a função de testemunha do analista vai de par, em Ferenczi, com sua concepção de repetição que, como vimos, não implica a reprodução do mesmo, 
mas faz advir o que nunca houve, o que jamais teve lugar. No sonho, a repetição encenada pretende uma liquidação traumática que é, como vimos, limitada. A resolução do trauma exige o lugar da testemunha. Com ele, a rememoração ou repetição podem fazer que "uma nova espécie de resolução do trauma, mais vantajosa, e até mais duradoura também possa produzir-se" (Ferenczi, 1934/1992, p. 113). Ao participar desse lugar, o analista ultrapassa tanto a função interpretativa quanto a função de continente para as quais a situação clínica o convoca, criando uma memória que vai ser experimentada pela primeira vez.

Mas o que significa participar desse lugar terceiro? Em que condições e de que maneira o analista desempenha a função de testemunha? Quanto a isso, seria preciso marcar três pontos importantes. O primeiro é que na clínica do traumático, a função da testemunha nada tem a ver com o lugar do terceiro em uma situação de litígio, quando ele é requisitado para comprovar ou atestar alguma coisa. Essa situação pertence à esfera do direito e à instituição do tribunal, comumente associadas ao testemunho enquanto testis. Nesse mesmo sentido, quando pensamos o analista como testemunha, não o situamos no lugar do pai, do simbólico ou de uma lei capaz de dar fim ao litígio entre duas partes. A clínica do traumático não tem como objetivo fazer um sujeito aceder a uma ordem simbólica ou a uma estruturação psíquica segundo a ordem do recalque e da neurose. Um analista que se dispuser a esse papel não estará desempenhando mais do que uma função normativa, buscando encaixar o funcionamento psíquico de um sujeito clivado na esfera de uma subjetividade padrão.

Diferentemente desse terceiro concebido sob uma lógica estrutural, a função de testemunha do analista põe em jogo um lugar que não é o da lei ou da norma, mas o de algo que existe antes que qualquer forma se imponha. Esse lugar não poderia nem mesmo ser configurado com nitidez. Ele é intersticial, informe, nem dentro e nem fora, nem dizível nem visível, funcionando como laboratório de intensidades afetivas à procura de configuração. É o que sugere Monique Schneider (1992): nessa clínica, "o recurso ao epíteto 'ternário' permite cernir o espaço transicional que oferece as condições de possibilidade do que é visto como advento do triangular" (p. 77). Não se poderia nem mesmo dizer que o analista ocupa esse lugar; mais correto seria dizer que ele participa da instauração desse espaço transicional (Winnicott, 1971) - também chamado de "estado potencial" - ao exercer sua função de testemunha. Em um espaço como esse, as narrativas frequentemente fragmentadas, literais, confusas dos sujeitos traumatizados, poderiam ser acolhidas sem qualquer expectativa de coerência ou sistematicidade. O lugar da testemunha, portanto, seria mais o lugar do informe do que de um terceiro capaz de suspeitar das narrativas que escuta, prescrutando nelas uma posição subjetiva ou uma formação do inconsciente.

Um segundo ponto deve ser marcado quanto a esse lugar terceiro. Testemunhar, da parte do analista, não implica apenas acolher ou conter. Implica, primordialmente, reconhecer. $\mathrm{O}$ reconhecimento pode ser entendido como a necessidade vital que possui todo indivíduo de ser visto, ouvido, aprovado e respeitado pelo seu entorno. Não é difícil percebermos que a situação vivenciada como traumática para alguém é justamente aquela em que esse reconhecimento é recusado ou, nos termos de Ferenczi (1931/1992), é a situação na qual um sujeito é desmentido. Desse modo, o reconhecimento é visto como o oposto do desmentido que estaria na origem do aniquilamento subjetivo experimentado no trauma. Desmentir envolve o descrédito da percepção, do sofrimento e da própria condição de sujeito daquele que vivenciou o trauma, de forma que não se nega o evento, mas o sujeito. Reconhecer é o avesso disso: implica dar crédito ao trauma, validando as percepções e sentimentos daquele que sofreu a violência. Disso nos falam nossos pacientes, quando desconfiam de suas próprias percepções ou da gravidade de seu sofrimento: "talvez eu esteja exagerando, não é possível que tenha ocorrido desse modo, isso não pode ter acontecido". A importância e a forma afetiva desse reconhecimento dificilmente são levadas em conta em um trabalho psicanalítico clássico, quando um analista se orienta pela estratégia da suspeita. Sobre isso, Ferenczi escreve:

Parece que os pacientes não podem acreditar, pelo menos não completamente, na realidade de um evento, se o analista, única testemunha do que se passou, mantém sua atitude fria, sem afeto e, como os pacientes gostam de dizer, puramente intelectual, ao passo que os eventos são de natureza tal que devem evocar em toda pessoa presente sentimentos e reações de revolta, de angústia, de terror, de vingança, de luto. (Ferenczi, 1932/1990, p. 57, itálico nosso)

Cabe observar que o reconhecimento que aqui se coloca em jogo não se refere a qualquer noção de identidade. Esse ponto é importante: é preciso distinguir o problema ético do desmentido do problema moral das políticas identitárias contemporâneas, que se instituem em torno do reconhecimento de identidades sexuais, étnicas e culturais. Reconhecer uma identidade nesses moldes implica produzi-la sob uma nova condição, a de vítima. Mas não é esse o reconhecimento ao qual aludimos na clínica do traumático. Aí não se trata de reconhecer o que um sujeito é, mas sim de reconhecê-lo naquilo que ele pode ser, em suas potencialidades. Reconhecer a singularidade de alguém, nesses termos, significa abrir, em um presente congelado pelo traumatismo, suas possibilidades de futuro. Judith Butler (2006), teórica contemporânea do problema do reconhecimento, afirma que, ao fazê-lo, protegemos a possibilidade de um sujeito tornar-se algo que ainda não sabemos, e que nem ele mesmo sabe: "Demandar reconhecimento ou oferecê-lo não significa pedir que se reconheça o que cada um já é. Significa invocar um devir, instigar uma transformação, exigir um futuro" (p. 72). Daí a importância de um espaço de testemunho descrito como potencial.

Terceiro ponto: foi dito que a narrativa testemunhal envolvia um paradoxo. Ela narra o que aconteceu ao 
mesmo tempo que admite que esses acontecimentos não fazem parte do narrável. Esse paradoxo pode ser expresso de outra maneira, e Primo Levi (1990) o faz bastante bem:

Repito, não somos nós, os sobreviventes, as autênticas testemunhas ... Nós, sobreviventes, somos uma minoria anômala, além de exígua: somos aqueles que, por prevaricação, habilidade ou sorte, não tocamos o fundo. Quem o fez, quem fitou a górgona, não voltou para contar, ou voltou mudo: mas são eles, os "muçulmanos", os que submergiram - são eles as testemunhas integrais, cujo depoimento teria significado geral. (p. 47)

$\mathrm{Ou}$ seja, as verdadeiras testemunhas, as testemunhas integrais, são aquelas que, por terem tocado o fundo, não podem testemunhar. Morreram ou se tornaram mortos-vivos, homens-múmia, paralisados, imbecilizados. Os sobreviventes falam em seu lugar, sabendo que só testemunham pela impossibilidade de testemunhar. Assim, aquilo que é narrado nos relatos não é o essencial da experiência traumática. Sua vivência nua e crua permanece inenarrável.

O paradoxo apontado por Levi estaria presente na própria constituição do sonho traumático. Sonhar e narrar o sonho, ou melhor, transformar a experiência traumática num sonho que pode ser narrado, já implica certo nível de elaboração da experiência. Porém a situação traumática em si mesma não é sonhável nem narrável, uma vez que envolve, como escreve Ferenczi "a suspensão de toda espécie de atividade psíquica, somada à instauração de um estado de passividade desprovido de toda e qualquer resistência" (1934/1992, p. 113). A dissociação traumática também se verifica aqui: é como se houvesse um sujeito que fala, mas não tem nada muito interessante a dizer - um sujeito que sabe mas não sente - alguém muito vulnerável que vivenciou o trauma em sua radicalidade, ficando, com isso, destruído e sem palavras. Daí a necessidade de reconhecer o paradoxo de Levi - que é, de resto, o paradoxo de todo trauma. Para que o efeito terapêutico do testemunho se verifique, não basta narrar e ser ouvido; é preciso admitir que se narra a impossibilidade de narrar.

Sobre esse paradoxo, escreve Shoshana Felman (1990): "Realmente não é possível dizer a verdade, testemunhar a partir de fora. Mas nem sequer é possível testemunhar a partir de dentro." (p. 89). Ao que Agamben (2008) acrescenta, retocando o comentário: "É justamente o umbral de indistinção entre o dentro e o fora (que ... é algo bem diverso de uma "ponte" ou de um "diálogo") que poderia levar a uma compreensão da estrutura do testemunho" (p. 45). Esse paradoxo faz que o lugar onde o testemunho se dá deva ser, ele mesmo, paradoxal, intersticial, um limiar entre o dentro e o fora. Seligmann-Silva (2008) pensa que "talvez a busca deste local do testemunho seja antes uma errância, um abrir-se para sua assistematicidade, para suas fraturas e silêncios" (p. 78). Eis aí uma boa definição do que na clínica psicanalítica é experimentado como espaço potencial.
Trata-se de um espaço importante, porque permite que circule e ganhe forma algo que é incomunicável. Para que um paciente possa comunicar $o$ incomunicável, é preciso antes que o analista seja capaz de comunicar-se com o incomunicável, deixando-se tocar e afetar por ele. Isso quer dizer, em primeiro lugar, respeitar o direito do paciente à não-narração, ou à não-comunicação, ou ainda à narração fragmentária e assistemática. Winnicott sempre reforçou a importância de reconhecer o paciente em suas idiossincrasias e em sua relativa incomunicabilidade. Sempre advertiu sobre a necessidade de evitar que o paciente se sinta "apanhado", "pego no flagrante" de ser. A aceitação do mistério e do indizível seria parte fundamental do espaço potencial enquanto espaço de testemunho.

O testemunho se constrói entre o dentro e o fora nesse lugar que, paradoxalmente, une (busca integrar e dar pertencimento) ao mesmo tempo que separa (admite uma singularidade intocável). Reconhecer esse paradoxo - ou seja, suportá-lo ao invés de buscar solucioná-lo - seria não somente um gesto terapêutico, mas também uma conquista cultural e temporal. A esse respeito escreve Winnicott (1971):

Este paradoxo, uma vez aceito e tolerado, é valioso para todo indivíduo humano que não apenas está vivo e vivendo neste mundo, mas é também capaz de ser infinitamente enriquecedor em função da exploração do vínculo cultural com o passado e com o futuro. (p. XII)

\section{Um espaço de vagalumes}

Muito se fala, tanto nos sonhos traumáticos quanto na escrita testemunhal, da vivacidade das lembranças do trauma. "As recordações de meu cativeiro estão muito mais vivas e detalhadas do que qualquer outra coisa que aconteceu antes ou depois. Conservo uma memória visual e acústica das experiências de lá que não consigo explicar" (Levi, 1997, p. 225).

As lembranças traumáticas implicam uma presentificação muito vívida da experiência que a originou. Em sua Carta 52 a Fliess, Freud (1896/1996) fala de diversas modalidades de memória; uma delas é feita com traços mnêmicos, representações psíquicas; outra é feita com signos de percepção, isto é, com impressões sensíveis que não se inscreveram no psiquismo como traço. Freud nos propõe uma memória múltipla, que passa constantemente por transformações: as impressões sensíveis podem ser retraduzidas em traços mnêmicos, e desse modo podem ser representadas e dominadas. Ora, as impressões sensíveis são justamente o material que constitui as lembranças traumáticas: os traumas produzem impressões tão fortes que varrem toda a possibilidade de sua inscrição como traços mnêmicos. Essas impressões intensas não podem ser representadas, mas se presentificam como signos de percepção, conservando-se literalmente na memória.

É por esse motivo que as lembranças traumáticas aparecem como ultraclaras. São presentificações muito 
vívidas da experiência que as originou. As lembranças ultraclaras foram descritas por Freud (1937/1996) como algo próximo das alucinações, sendo por isso constituídas de forma semelhante aos sonhos traumáticos. Elas se encontram em um nível muito mais concreto (literal) do que as lembranças comuns, apresentando uma vivacidade sinestésica muito acentuada do que é figurado. Ainda assim, Freud considera que existe aí uma memória, a memória dos signos de percepção, que se mantém pouco alterada e ultraclara.

Testemunhar é trabalhar as lembranças ultraclaras com o intuito de obscurecê-las. Sim, é exatamente essa a palavra: obscurecer. Reduzir a luz ofuscante das lembranças ultraclaras - só assim se pode diminuir o poder mortífero do trauma sobre o eu. Didi-Huberman (2011) apresenta, em A sobrevivência dos vagalumes, um comentário interessante sobre a releitura que o cineasta Pier Paolo Pasolini faz da Divina Comédia. Na obra de Dante Alighieri, o paraíso é descrito como um lugar resplandecente, inteiramente tomado por uma grande luz ofuscante. Já na descrição do inferno, Dante reserva um lugar discreto às pequenas luzes fugidias dos vagalumes ou centelhas, correspondendo ao lugar dos políticos pérfidos. Há um contraste entre a grande luz que se dilata em todas as direções no paraíso e o bruxuleio dos vagalumes no inferno, onde cada centelha contém um político traiçoeiro ardendo nas pequenas brasas.

Em uma crônica de 1975, Pasolini inverte as posições do bem e mal, ou do paraíso e inferno de Dante. Compara a luz ofuscante dos projetores contemporâneos à propaganda fascista na Itália e na Alemanha, e a resistência antifascista aos vagalumes fugidios que emitem seus sinais discretos, porém insistentes - sinais de vida, de resistência. O universo dantesco, dessa forma, se inverte: "é o inferno que a partir de então, é exposto com seus políticos desonestos, superexpostos, gloriosos. Quanto aos lucciole (vagalumes), eles tentam escapar como podem à ameaça, à condenação que a partir de então atinge sua existência" (Didi-Huberman, 2011, p. 17). Notemos, então, que não é na noite, na escuridão, que os vagalumes desaparecem, mas diante da grande claridade representada pelo perigo fascista, na qual a diferença inexiste. Não se poderia notar a presença dos vagalumes no paraíso devido à intensa claridade, a partir da qual tudo se torna indiferente e monótono.

O trauma implica justamente um acontecimento tão poderoso que ofusca os demais, provocando uma ruptura no eu e um colapso no aparelho psíquico. No ensaio A literatura do desastre, escrito todo em fragmentos para acompanhar a própria fragmentação que o desastre/trauma acarreta na linguagem, Blanchot (1987) afirma: "noite, noite branca - assim é o desastre, essa noite à qual falta obscuridade, sem depuração da luz" (p. 10, tradução nossa). Assim também é a memória do trauma: ultraclara, tão clara e vívida que ofusca as demais memórias do sujeito, aparecendo compulsivamente sem ser convidada. Os testemunhos são, sob esse viés, formas de resistir, de sobreviver - atos de saúde, de vida, pois ao narrar suas catástrofes subjetivas, os sujeitos empreendem uma luta para obscurecer a claridade devoradora do traumático. Testemunhar dá chance aos vagalumes aparecerem como pequenas luzes fragmentárias, fugazes e frágeis; luzes de Eros que procuram resistir ao terror - são lampejos de esperança e vida que pululam em meio à repetição compulsiva. São sinais de resistência da vida face à morte através de fulgurações figurativas que se dão pela narrativa oral ou escrita, dando voz ao que antes fora vivido como impotência e silêncio.

Era arrebatador buscar e encontrar, ou criar, a palavra justa, isto é, proporcionada, exata e forte; extrair as coisas da memória e descrevê-las com o máximo de rigor e o mínimo de embaraço. Paradoxalmente minha bagagem de memórias atrozes se tornava uma riqueza, uma semente; ao escrever, eu parecia crescer como uma planta. (Levi, 1994, p. 153)

A palavra justa seria um bruxuleio do real, fugaz e impactante; ela seria uma espécie de decantação ou desconstrução da própria representação, fazendo o relato se aproximar ao máximo do acontecimento traumático. Isso significa criar palavras onde elas sequer existem. Poderíamos então aproximar o testemunho e o sonho traumático, pensando a linguagem usada na literatura de testemunho como presentificação, na medida em que o relato é evocado diretamente dos signos de percepção. $\mathrm{O}$ testemunho leva mais adiante um movimento que o sonho apenas esboçara ao fornecer às impressões sensíveis um primeiro contorno imagético. Oscilando entre a representação e a presentificação através da palavra, o testemunho se exerce na proximidade e/ou distância entre as palavras e as coisas. Daí encontrarmos com frequência nos superstites uma literalidade narrativa, uma linguagem dissecada e isenta de entrelinhas que toca o fundo doloroso da experiência. $\mathrm{Ou}$ como sugere Cayrol (1964): o sobrevivente "raspa as ideias como a garça raspa com o bico a superfície da água de um rio" (p. 221). A narrativa do trauma traz o fragmento, a repetição, o detalhe não polido pela metáfora, a crueza e aspereza de uma experiência de encontro com a morte. Esta sim, a literalidade absoluta.

Se há uma descontinuidade nos relatos, é porque o testemunho nasce dos signos de percepção e dos fragmentos egoicos. O que vai fazer diferença, permitindo que as conexões entre os fragmentos possam se estabelecer, é a possibilidade de endereçá-los a alguém: contar a história e ser ouvido, lido, reconhecido num espaço clínico ou comunitário que aceite e compartilhe os titubeios, a ausência de ordem cronológica, o sofrimento da experiência. No caso da literatura de testemunho, essas conexões poderão surgir a partir do encontro entre livro e leitor. Da atitude do leitor - a testemunha do testemunho - dependerá a chance de vislumbrar os vagalumes: afinal, é para alguém que se escreve esses sinais de resistência e apelo. Didi-Huberman (2011) diz que os vagalumes "desaparecem apenas na medida em que o espectador renuncia a segui-los. Eles desaparecem de sua vista porque o espectador se mantém em seu lugar, e este não é o melhor lugar para vê-los" (p. 47). Daí a 
importância de cultivar, na recepção dos testemunhos, um lugar em que a luz - entendida como espetacularização, expectativa de coerência e de soluções - não seja ofuscante, e haja penumbra suficiente para dar visibilidade - e ouvido - aos pequenos sinais.

A literatura de testemunho, nessa perspectiva, nos lança em um devir outro, numa alteridade que não é apenas a do outro, mas a nossa própria. É daí que deriva o nosso incômodo; ela nos faz também testemunhas, participantes de algo intraduzível. Para isso nos arrastam as narrativas testemunhais, movimento do qual muitas vezes tentamos escapar, mas que para os superstites aparece como imperioso. Primo Levi e Semprun falam da necessidade de narrar que acossa os sobreviventes: "a necessidade de contar aos outros, de tornar os outros participantes, alcançou entre nós, antes e depois da libertação, caráter de impulso imediato e violento" (Levi, 1988, p. 8); contar para esses outros que vieram de fora, "vindos da vida" (Semprun, 1995, p. 23). Quando esses outros vindos da vida testemunham o "invivível" - como se refere Semprun (1995) aos acontecimentos do Lager - abre-se a possibilidade de as memórias traumáticas (ultraclaras) serem obscurecidas.

Contudo, para testemunhar o invivível, é preciso que eles se disponham a sair de seu lugar. Sobre isso escreve Jeanne-Marie Gagnebin (2001): "testemunha não seria somente aquele que viu com seus próprios olhos, ... seria também aquele que não vai embora, que consegue ouvir a narração insuportável do outro e que aceita que suas palavras revezem a história do outro". (p. 93). Revezamento que não pode ocorrer quando o encontro se dá a partir de lugares demarcados. Ele exige um espaço de contínua passagem entre o eu e o outro, o ser e o não ser, a palavra e o silêncio.

A noção de espaço potencial como espaço de testemunho seria, nesse sentido, uma contribuição mais efetiva ao trabalho com sobreviventes de situações extremas do que a simples compreensão da teoria do trauma. Na clínica, trata-se de um lugar que o analista não ocupa, mas sustenta e suporta. Sustenta a indeterminação desse espaço e o fato de ele não estar orientado para um objetivo, ou seja, sua possível ausência de sentido e de forma. Sustenta-o como espaço de paradoxo, no qual se pode narrar a impossibilidade de narrar. Sustenta-o, como propõe Ferenczi, com sua capacidade de "sentir com (Einfühlung)" (Ferenczi, 1928/1992, p. 31), que o permite reconhecer e ressoar o sofrimento de seu paciente, abrindo-se a esse outro, ou melhor, ao devir que vem do outro. Isso não significa identificar-se com o outro, fazendo da experiência analítica uma experiência de alienação no outro; significa acompanhar as variações afetivas e deixar-se sensibilizar por elas, engajando-se num jogo em que os lugares e as palavras possam ser revezados.

Clinicamente, não se trata de interpretar, mas de suportar. Suportar a literalidade da narração testemunhal e o peso que dela provém não são nada fáceis para o analista nem para qualquer ouvinte. Esse encontro, baseado no suporte, cria espaço para o aparecimento dos vagalumes. Eles só vêm quando os seguimos, quando, a partir de uma narrativa literal, nos abrimos à experiência de efetivamente ter estado lá onde nunca estivemos - momento em que o lugar terceiro (terstis) se torna também, e ao mesmo tempo, o lugar da vivência direta (superstes).

\section{The analyst as a witness}

Abstract: The aim of this article is to think of the place of the witness as a third place that the analyst, in the clinic of trauma, is able to sustain. According to Ferenczi, in traumatic dreams a third is already being summoned. It is not the witness of the realm of Law, nor the place of the father or the symbolic Law. This is a third space that can be called potential, interstitial space, indeterminate and formless, where something that at first would be incommunicable circulates - and gradually takes shape. This space allows and supports the literalness of a testimonial narrative, its hesitations, paradoxes and silences. More than a trauma theory, the notion of a potential space would be the great contribution of psychoanalysis to the theoretical and clinical research with survivors of death camps, situations of torture and violence.

Keywords: trauma, witness, potential space, clinic, psychoanalysis.

\section{L'analyste en tant que témoin}

Resumé: Le but de cet article est de penser à la place du témoin en tant qu'espace troisième que l'analyste, dans la clinique du traumatique, est capable de supporter. Dans les rêves traumatiques, selon Ferenczi, il y a déjà la convocation d'un troisième. II ne s'agit pas du témoin de la sphère du Droit, ni de la place du Père ou de la Loi symbolique. Il s'agit d'un troisième espace qui peut être nommé potentiel, espace interstitiel, indéterminé et sans forme où circule, et peu à peu prend forme, quelque chose d'abord incommunicable. Cet espace permet et soutient la littéralité du récit testimonial, ses hésitations, ses paradoxes et ses silences. En plus qu'une théorie du traumatisme, la notion d'espace potentiel serait une grande contribution de la psychanalyse à la recherche théorique et clinique avec des survivants des camps d'extermination, des cas de torture et de violence.

Mots-clés: trauma, témoin, espace potentiel, clinique, psychanalyse. 


\section{El analista como testigo}

Resumen: La propuesta de este artículo es pensar el lugar del testigo como un tercer lugar que el analista, en la clínica del traumático, es capaz de sostener. De acuerdo con Ferenczi, en los sueños traumáticos la convocación de un tercero ya existe. No se trata del testimonio del reino del Derecho, tampoco del lugar del padre o de la Ley simbólica. Se trata de un tercer espacio que se puede llamar potencial, el espacio intersticial, indeterminado y sin forma en el cual algo que al principio sería incomunicable circula y toma forma poco a poco. Este espacio permite y apoya la literalidad de la narrativa testimonial, sus vacilaciones, paradojas y silencios. Más que una teoría del trauma, la noción de espacio potencial sería la gran contribución del psicoanálisis a la investigación teórica y clínica con sobrevivientes de campos de exterminio, de los casos de tortura y violencia.

Palabras clave: trauma, testigo, espacio potencial, clínica, psicoanálisis.

\section{Referências}

Agamben, G. (2008). O que resta de Auschwitz: o arquivo e a testemunha (Homo Sacer III). São Paulo, SP: Boitempo.

Benveniste, E. (1995). O vocabulário das instituições indoeuropeias (Vol. 2: Poder, direito, religião). Campinas, SP: Ed. Unicamp.

Blanchot, M. (1987). La escritura del desastre. Venezuela: Monte Avila.

Butler, J. (2006). Vida precária: el poder del duelo y la violencia. Buenos Aires: Paidós.

Cayrol, J. (1964). Les corps étrangers. Paris: U.G.U.

Derrida, J. (1995). Freud e a cena da escritura. In A escritura e a diferença. São Paulo, SP: Perspectiva (Originalmente publicado em 1967)

Didi-Huberman, G. (2011). Sobrevivência dos vaga-lumes. Belo Horizonte: Ed. UFMG.

Felman, S. (1990). À 1'âge du témoignage: Shoah de C. Lanzmann. In Au sujet de Shoah. Paris: Belin.

Ferenczi, S. (1991). A respeito das psiconeuroses. Obras completas de Sándor Ferenczi, Psicanálise 1. São Paulo, SP: Martins Fontes. (Trabalho original publicado em 1909)

Ferenczi, S. (1992). A elasticidade da técnica psicanalítica. Obras completas de Sándor Ferenczi, Psicanálise 4. São Paulo, SP: Martins Fontes. (Trabalho original publicado em 1928)

Ferenczi, S. (1992). Análise de crianças com adultos. Obras completas de Sándor Ferenczi, Psicanálise 4. São Paulo: Martins Fontes. (Trabalho original publicado em 1931)

Ferenczi, S. (1990). Diário clínico. São Paulo, SP: Martins Fontes. (Trabalho original publicado em 1932)

Ferenczi, S. (1992). Reflexões sobre o trauma. Obras completas de Sándor Ferenczi, Psicanálise 4. São Paulo, SP: Martins Fontes. (Trabalho original publicado em 1934)
Freud, S. (1996). Carta 52. Edição standard brasileira das obras psicológicas completas de Sigmund Freud (Vol. 1. pp. 281-287.). Rio de Janeiro: Imago. (Trabalho original publicado em 1896[1950])

Freud, S. (1996). Construções em análise. Edição standard brasileira das obras psicológicas completas de Sigmund Freud (Vol. 23. pp. 275-287). Rio de Janeiro, RJ: Imago. (Trabalho original publicado em 1937)

Gagnebin, J. M. (2001). Memória, história, testemunho. In S. Bresciani \& M. Naxara (Orgs.), Memória e (res) sentimento. Indagação sobre uma questão sensível (pp. 85-94). Campinas, SP: Ed. Unicamp.

Levi, P. (1988). É isto um homem? Rio de Janeiro, RJ: Rocco.

Levi, P. (1990). Os afogados e os sobreviventes. Rio de Janeiro, RJ: Paz e Terra.

Levi, P. (1994). A tabela periódica. Rio de Janeiro, RJ: Relume-Dumará.

Levi, P. (1997). Conversazioni e interviste. Torino: Einaudi.

Schneider, M. (1992). La part de l'ombre. Approche d'um trauma feminin. Paris: Aubier.

Seligmann-Silva, M. (2008). Narrar o trauma. Psicologia Clínica, 20(1), 65-82.

Seligmann-Silva, M. (2010). O local do testemunho. Tempo e argumento, 1(2), 3-20.

Semprun, J. (1995). A escrita ou a vida. São Paulo, SP: Companhia das Letras.

Winnicott, D. W. (1971). The place where we live. In Playing and reality. London: Tavistock. 